\title{
PAPAN HURUF FLANEL: MEDIA PEMBELAJARAN KEAKSARAN AWAL UNTUK ANAK USIA DINI
}

\author{
Jazariyah \\ Institut Agama Islam Negeri Syekh Nurjati Cirebon \\ E-mail: jazariyah@syekhnurjati.ac.id
}

Article received: 14 September 2019, Review process: 16 September 2019

Article published: 30 September 2019

\begin{abstract}
Attractive learning media become an attraction in early childhood learning. The use of media can provides convenience for teachers of Early childhood education (PAUD) in delivering material to be given to children. This study aims to conduct development research in making learning media. The media developed is alphabet flannel board (letter board). This media development was carried out for the introduction of early literacy, using the Research and Development $(R \& D)$ research model. The stages of $R \& D$ research include potential problems, information gathering, product design, design validation, design revisions, products, small-scale product trials, large-scale trials and mass production. In this study not all stages are carried out considering the limited time and cost so that the research only reaches the stage of feasibility validation and design revision to be the final product. Feasibility of the Alphabet Flannel Board is validated by the expert and the assessment of the user in this case PAUD teacher. Based on data analysis, the results of this study indicate that the Alphabet Flannel Board is quite feasible to be used as media. The mean value of the validation shows 3.25 of a scale of 5 which means it's quite decent.
\end{abstract}

Keyword: Alphabet Flannel Board, Learning Media, Early Literacy

\begin{abstract}
Abstrak
Media pembelajaran menarik menjadi satu daya tarik dalam pembelajaran anak usia dini. Penggunaan media dapat memberikan kemudahan bagi guru Pendidikan anak usia dini (PAUD) dalam menyampaikan materi yang akan diberikan pada anak. Penelitian ini bertujuan untuk melakukan penelitian pengembangan dalam pembuatan media pembelajaran. Media yang dikembangkan adalah papan Huruf. Pengembangan media ini dilakukan untuk pengenalan keaksaraan awal, dengan menggunakan model penelitian Research and Development (R \& D). Tahapan penelitian R \& D mencakup potensi masalah, pengumpulan informasi, desain produk, validasi desain, revisi desain, produk, uji coba produk skala kecil, uji coba skala besar dan produksi massal. Pada penelitian ini tidak semua tahapan dilaksanakan mengingat keterbatasan waktu dan biaya sehingga penelitian hanya sampai tahap validasi kelayakan dan revisi desain menjadi produk akhir. Kelayakan Papan Huruf divalidasi oleh ahli dan penilaian dari pengguna dalam hal ini guru PAUD. Berdasarkan
\end{abstract}


AWLADY: Jurnal Pendidikan Anak

Homepage: www.syekhnurjati.ac.id/jurnal/index.php/awlady

Email : pgrasyekhnurjati@gmail.com

P-ISSN: 2541-4658

E-ISSN: 2528-7427
Vol. 5, No. 2, September 2019

analisa data, hasil penelitian ini menunjukkan bahwa papan huruf cukup layak untuk dijadikan media. Nilai Hasil rerata validasi menunjukkan 3,25 dari skala 5 yang artinya cukup layak.

Kata kunci: Papan Huruf Flanel, Media Pembelajaran, Keaksaraan Awal

\section{PENDAHULUAN}

Pendidikan anak usia dini menjadi pondasi untuk pendidikan selanjutnya. Pada masa usia dini, seorang anak mengalami perkembangan yang signifikan. Perkembangan anak di masa usia dini ini akan memberikan pengaruh terhadap keberlanjutan perkembangan anak di masa yang akan datang. Kondisi tersebut mengakibatkan keberadaan Pendidikan Anak Usia Dini (PAUD) tidak dapat lagi diremehkan. Keberhasilan anak bangsa, yang akan membangun negeri ini dipengaruhi oleh bagaimana para pendidik anak usia dini. Stimulasi yang diberikan pendidik dalam mengembangkan semua aspek perkembangan anak harus sesuai dengan harapan pada standar tingkat pencapaian perkembangan anak (STPPA).

Pencapaian perkembangan anak di tiap tiap tahapan usia memiliki target target yang berbeda. Aspek perkembangan anak terdiri dari aspek kognitif, bahasa, nilai agama dan moral, seni, fisik dan motorik serta sosial emosional. Keenam aspek perkembangan tersebut memiliki standar pencapaian di setiap tahapan usia. Pencapaian tersebut berlaku secara berkesinambungan, tahapan perkembangan di usia terendah akan mempengaruhi pencapaian pada tahapan usia selanjutnya.

Pencapaian perkembangan anak usia dini di tiap tahapan usia yang harus dipenuhi secara berkesinambungan mengakibatkan pentingnya bagaimana stimulasi yang diberikan dapat dilakukan secara tepat. Ketidakberhasilan pencapaian perkembangan anak di tahapan usia tertentu akan mempengaruhi keberhasilan anak dalam mencapai tahapan selanjutnya. Salahsatu yang sering menjadi masalah dalam pemenuhan target pencapaian perkembangan anak adalah pada ketercapaian target pengenalan keaksaraan awal pada anak usia dini.

Pemerintah sebagai pemangku kebijakan telah mengeluarkan beberapa aturan untuk mengatur standar tingkat pencapaian perkembangan anak usia dini. Standar tingkat pencapaian perkembangan anak yang dinyatakan oleh permendiknas 58 tahun 2009 di lingkup perkembangan kognitif untuk anak usia 3- 5 tahun, pada konsep bilangan, lambang bilangan 
AWLADY: Jurnal Pendidikan Anak

Homepage: www.syekhnurjati.ac.id/jurnal/index.php/awlady

Email : pgrasyekhnurjati@gmail.com

P-ISSN: 2541-4658

E-ISSN: 2528-7427
Vol. 5, No. 2, September 2019

1-10 dan huruf, yaitu menyebutkan bilangan, mengenal konsep bilangan, mengenal lambang bilangan dan mengenal lambang huruf (Ratnasari Dwi Ade Chandra, 2017).

Pada peraturan berikutnya yakni permendikbud 137 tahun 2014 di usia 3-4 tahun untuk perkembangan kognitif dalam hal pemecahan masalah salah satu pencapaian yang harus dituntaskan adalah anak mampu mengenal beberapa huruf atau abjad tertentu dari A-Z yang pernah dilihatnya. Pencapaian pada tahapan ini akan jadikan dasar untuk pencapaian perkembangan aspek bahasa pada tahapan selanjutnya. Pada pengenalan keaksaraan di usia 4-5 tahun, anak dapat meniru menuliskan dan mengucapkan huruf A-Z. Pencapaian tahapan ini kemudian menjadi dasar untuk mencapai perkembangan bahasa dalam hal keaksaraan yakni di usia 5-6 tahun, seorang anak usia dini harus mampu menyebutkan simbol-simbol huruf yang dikenal (Kemdikbud, 2014).

Konsep dasar huruf, angka dan warna penting untuk diajarkan sebagai kemampuan dasar matematika dan sains dalam rangka penyelasaian masalah. Sepanjang pembelajaran saat ini pengenalan huruf, angka, dan warna dilakukan oleh guru melalui bantuan buku atau kartu membaca. Fitri Indrayani dan Kurniasih R Sihite mengenalkan pembelajaran berbasis multimedia untuk pengenalan konsep dasar huruf, angka dan warna pada anak usia dini. Multimedia menawarkan animasi dan pembelajaran interaktif dalam penanaman konsep tersebut sehingga anak lebih mudah memahami dan tidak mudah bosan (Indriyani \& Sihite, 2015).

Pembelajaran huruf dan angka kembali menjadi fokus penelitian yang dilakukan oleh Lovandri Dwanda Putra dan Ishartiwi. Penelitian yang mereka lakukan berupa penelitian pengembangan dimana dimaksudkan untuk dapat menghasilkan produk multimedia pembelajaran. Penelitian ini menggunakan model pengembangan Lee \& Owens yang mencakup tiga tahapan yakni (1) perencanaan, (2) tahap desain dan (3) tahap pengembangan (Putra \& Ishartiwi, 2015).

Pengenalan huruf atau keaksaraan pada anak usia dini juga dilakukan melalui media tutup botol hias. Penelitian tindakan kelas dilakukan oleh Elok Siti Muflikha, hasil dari penelitian yang dilakukan menunjukan adanya peningkatan kemampuan anak mengenal huruf melalui media tutup botol hias (Muflikha, 2013). 
AWLADY: Jurnal Pendidikan Anak

Homepage: www.syekhnurjati.ac.id/jurnal/index.php/awlady

Email : pgrasyekhnurjati@gmail.com

P-ISSN: 2541-4658

E-ISSN: 2528-7427
Vol. 5, No. 2, September 2019

Pengenalan huruf dapat dilakukan dengan berbagai media dan bentuk seperti menyanyi, tebak huruf, puzzle, dan pohon huruf. Pohon huruf merupakan media pembelajaran yang terbuat dari papan triplek, kain flannel dan bola plastik dimana digunakan dengan tujuan agar menarik perhatian anak sehingga meningkatkan konsentrasi dalam pembelajaran pengenalan huruf vocal khususnya. Selain itu dapat mengembangkan potensi anak pada dimensi auditori, visual dan memori (Maulidya, Sa'dullah, \& Lismanda, 2019)

Dalam rangka pencapaian target pengenalan keaksaraan awal seperti yang diamanahkan pada permendikbud tersebut, seorang anak usia dini harus distimulasi dengan baik oleh para pendidik PAUD di lembaga masing masing. Proses pembelajaran yang dilakukan harus sedemikian rupa dengan media yang tepat sehingga anak usia dini dapat terstimulasi dengan baik. Penggunaan teknologi bahkan sudah dilakukan sejak dini sebagai media pembelajaran, salah satu contohnya penggunaan aplikasi pada android.

Salah satu materi yang diberikan pada pendidikan usia dini berupa pengenalan huruf, angka dan warna dilakukan melalui gambar dan latihan yang dibuat menarik. Aplikasi mobile pengenalan huruf, angka dan warna berbasis android yang bersifat belajar dan bermain banyak dikembangkan (Fitriyani, Tresnawati, \& Hadiyanto, 2014).

Belajar mengenal huruf merupakan komponen hakiki dari perkembangan baca tulis. Anak perlu mengetahui atau mengenal dan memahami huruf abjad untuk akhirnya menjadi pembaca dan penulis yang mandiri dan lancar. Anak- anak yang bisa mengenal dan menyebut huruf-huruf pada daftar abjad dalam belajar membaca memiliki kesulitan lebih sedikit dari anak yang tidak mengenal huruf (Pangastuti \& Farida, 2017)

Lingkungan rumah adalah sumber kemungkinan pengalaman yang dapat meningkatkan perkembangan bahasa lisan dan keterampilan keaksaraan awal. Beberapa anak usia dini sudah dapat mengenali huruf dengan baik namun adapula yang belum mampu mengenali huruf sama sekali. Orangtua dalam hal ini memiliki peran dalam membantu anak untuk dapat menguasai keaksaraan awal. Bentuk keterlibatan orang tua yang dapat dilakukan dalam mengembangkan kemampuan literasi dini anak antara lain dengan kegiatan membaca buku cerita bersama-sama, sering mengajak anak bercakap-cakap, sering bercerita kepada anak, bernyanyi bersama anak, dan masih banyak lagi (Nuraeni, 2016). Diantara kegiatan 
AWLADY: Jurnal Pendidikan Anak

Homepage: www.syekhnurjati.ac.id/jurnal/index.php/awlady

Email : pgrasyekhnurjati@gmail.com

P-ISSN: 2541-4658

E-ISSN: 2528-7427

lainnya dapat pula orangtua bersama sama mengajak anak usia dini untuk memainkan permainan edukatif untuk pengenalan huruf.

Mengingat pentingnya pengenalan huruf sejak dini sebagai komponen hakiki dalam kemampuan membaca, maka media pembelajaran yang digunakan oleh pendidik anak usia dini semestinya disesuaikan dengan tahapan anak usia dini. Untuk itu penelitian ini diarahkan untuk melakukan pengembangan media pembelajaran untuk pengenalan keaksaraan awal berupa papan huruf. Produk yang dihasilkan dalam penelitian ini berupa papan huruf yang dibuat dari flannel dan tutup botol bekas. Berbeda dengan penelitian sebelumnya yang lebih mengedapankan penggunaan teknologi untuk menghasilkan media pembelajaran interaktif, pada penelitian ini lebih menekankan pada pemanfaatan bahan bekas.

\section{METODOLOGI}

Penelitian ini menggunakan metode penelitian pengembangan atau Research and Development (R \& D). Model penelitian R \& D dalam penelitian ini mengadaptasi langkahlangkah dari Sugiyono. (Sugiyono, 2013). Prosedur penelitian pengembangan menurut Sugiyono dilakukan melalui 10 tahapan yakni; (1) Potensi dan masalah, (2) Pengumpulan data, (3) desain produk, (4) validasi desain, (5) Revisi desain produk, (6) Uji coba produk, (7) Revisi Produk, (8) Uji Coba pemakaian, (9) Revisi produk, dan (10) produksi terbatas. Adapun langkah yang diambil dalam penelitian ini sebagai berikut:

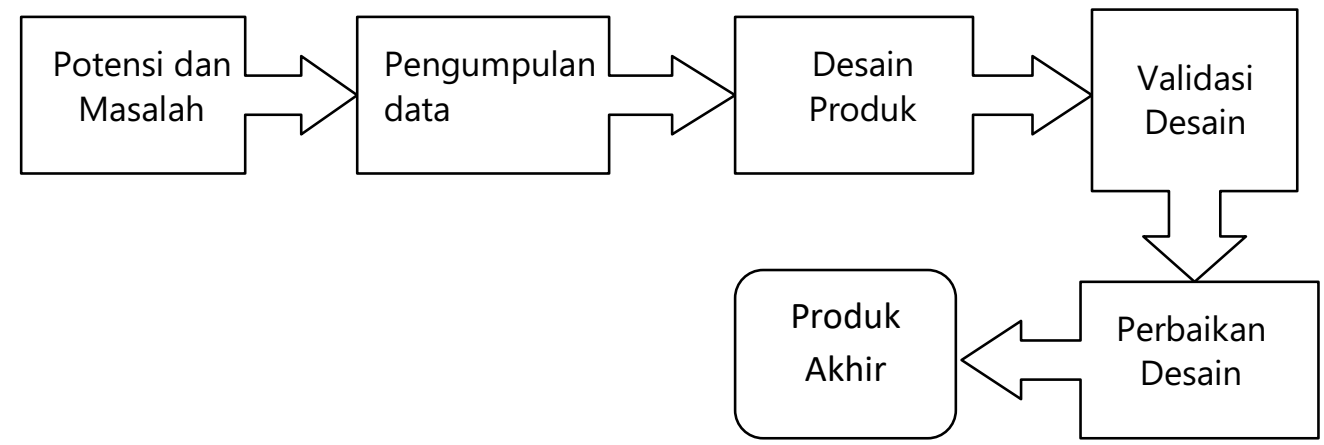

Gambar 1. Langkah-Langkah Penelitian R \& D yang dilakukan

Produk yang dihasilkan pada penelitian ini tidak sampai pada uji coba produk secara luas. Namun hanya melalui tahapan validasi ahli terkait desain serta perbaikan desain berdasarkan masukan dari ahli media dan pengguna media (guru) selanjutnya dijadikan sebagai produk akhir. 
AWLADY: Jurnal Pendidikan Anak

Homepage: www.syekhnurjati.ac.id/jurnal/index.php/awlady

Email : pgrasyekhnurjati@gmail.com

P-ISSN: 2541-4658

E-ISSN: 2528-7427
Vol. 5, No. 2, September 2019

Instrumen yang digunakan untuk pengumpulan data pada penelitian ini, berupa lembar observasi untuk analisa potensi masalah dan kebutuhan media yang tepat serta angket (form validasi) untuk ahli materi dan media serta pengguna (pendidik PAUD). Angket digunakan untuk mengumpulkan data-data kuantitatif yang kemudian akan dikonversikan menjadi data kualitatif.

Produk yang dikembangkan adalah Papan Huruf, produk ini dikembangkan dengan menggunakan bahan card board (Kertas karton tebal) dan kain flanel serta tutup botol bekas. Media ini terdiri dari papan huruf dan flanel huruf Papan huruf merupakan papan yang terdapat huruf-huruf alphabet baik vokal maupun konsonan. Huruf-huruf tersebut dicetak dalam kain Flanel dan ditempelkan pada tutup botol bekas, selain itu flanel huruf adalah potongan flanel lingkaran yang ditempel dengan pola huruf dari flanel. Instrumen yang digunakan dalam penelitian ini berupa angket penilaian validasi yang diberikan kepada ahli media serta beberapa guru sebagai pengguna media.

\section{HASIL DAN PEMBAHASAN}

Penggalian informasi dan identifikasi permasalahan dilakukan sebagai tahapan awal dalam penelitian pengembangan ini. Melalui observasi pada lembaga pendidikan anak usia dini (PAUD). Observasi dilakukan untuk mengetahui bagaimana pemanfaatan media yang dilakukan oleh pendidik dalam upaya pengenalan keaksaraan awal. Selain itu pada tahapan awal dilakukan kajian terhadap literatur yang terkait dengan pengenalan keaksaraan awal, sehingga media yang akan dikembangkan nanti tepat guna dan sesuai dengan kebutuhan.

Hasil observasi menunjukkan salah satu yang media yang digunakan dalam pengenalan keaksaraan awal salah satunya adalah penggunaan buku cerita. Buku bacaan yang disediakan lembaga PAUD ada beberapa yang berupa buku cerita tematik. Adanya buku cerita tematik ini dapat dijadikan sebagai media untuk kegiatan membaca permulaan. Penggunaan buku bacaan ini atau buku cerita tematik, merujuk pada saran sebuah penelitian dimungkinkan dapat meningkatkan kemampuan pengenalan huruf dan motivasi membaca anak (Izzaty, Cholimah, \& Wulandari, n.d.).

Penggunaan media lain yang umum digunakan adalah kartu baca, atau kartu huruf, dari 10 lembaga yang dijadikan tempat observasi separuhnya memiliki kartu huruf yang dimanfaatkan untuk pengenalan keaksaraan pada anak usia dini. Peningkatan kemampuan 
AWLADY: Jurnal Pendidikan Anak

Homepage: www.syekhnurjati.ac.id/jurnal/index.php/awlady

Email : pgrasyekhnurjati@gmail.com

P-ISSN: 2541-4658

E-ISSN: 2528-7427
Vol. 5, No. 2, September 2019

anak dalam mengenali huruf melalui kartu huruf ataupun flash card dapat memicu pembelajaran yang aktif dan menyenangkan, anak usia dini terlibat secara aktif dalam pembelajaran yang berlangsung (Suhermin, 2019).

Media-media yang ditemui di lembaga PAUD yang dijadikan objek obervasi ternyata belum memiliki nilai pemanfaatan bahan yang ada disekitar. Lembaga cenderung mengesampingkan ketrampilan pendidik dalam pengembangan media pembelajaran. Berikut gambaran ketersedian media yang digunakan beberapa lembaga yang diobservasi dalam pengkategorian media handmade (kreasi guru), media produk jadi (media yang dibeli di pasaran), buku dan Majalah serta Media Berbasis IT (Teknologi, berupa Ipad untuk pengenalan huruf dan hijaiyah untuk anak)

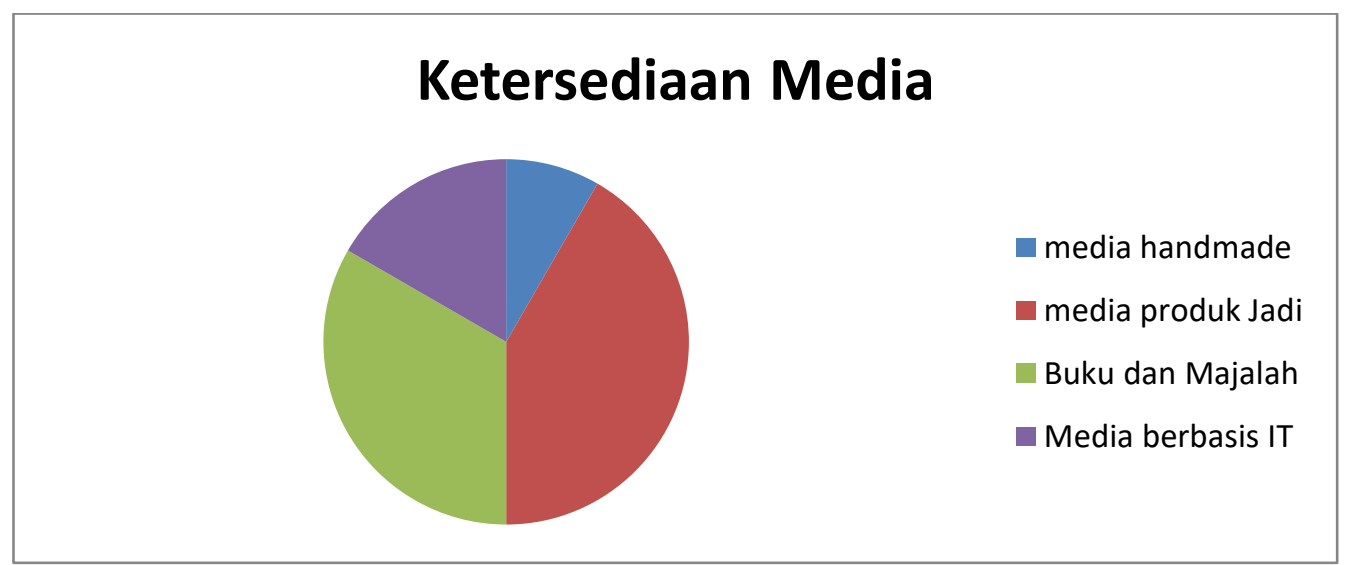

\section{Gambar 2. Diagram Ketersediaan Media}

Penggunaan media berupa produk jadi seperti flash card, Kartu Bergambar, Puzzle Huruf dan sebagainya masih menjadi trend media yang digunakan oleh lembaga dalam pengenalan keaksaraan awal. Menempati urutan kedua yang menjadi media untuk mengenalkan huruf adalah buku dan majalah, dimana di dalam buku tersebut terdapat lembar kerja anak seperti menebalkan huruf dan pengenalan kosakata.

Kemampuan membaca permulaan dimulai dari kegiatan menebalkan huruf, menebalkan huruf yang dibuat melalui lembar kerja anak, dimana dalam lembar kerja tersebut terdapat garis titik - titik yang dapat dihubungkan dan membentuk lambang huruf (Ramadani, 2015). Kegiatan semacam ini berdasarkan wawancara dilapangan dengan para pendidik 
AWLADY: Jurnal Pendidikan Anak

Homepage: www.syekhnurjati.ac.id/jurnal/index.php/awlady

Email : pgrasyekhnurjati@gmail.com

P-ISSN: 2541-4658

E-ISSN: 2528-7427
Vol. 5, No. 2, September 2019

seringkali mengakibatkan kebosanan pada anak usia dini, sehingga tidak memberikan motivasi pada anak usia dini untuk belajar mengenal huruf.

Pengenalan huruf menjadi salah satu target dari kompetensi pengenalan keaksaraan awal pada aspek pengembangan bahasa. Materi yang menjadi target lain yaitu: 1) Membaca gambar, membaca simbol ; 2) Menjiplak huruf; 3) Mengenal huruf awal di namanya, menuliskan huruf-huruf namanya; 4) Menuliskan pikirannya, walaupun hurufnya masih terbalik atau tidak lengkap; 5) Hubungan bunyi dengan huruf; 6) Mengucapkan kata yang sering diulang-ulang tulisannya pada buku cerita; 7) Mengeja huruf; 8) Membaca sendiri, dan 9) Hubungan angka dan bilangan (Yennizar, 2018).

Target pencapaian tersebut dapat diawali dengan mengenalkan simbol huruf pada anak usia dini melalui media yang menyenangkan dan mudah dikembangkan. Kreativitas guru dalam memilih media pembelajaran yang digunakan mampu mempengaruhi hasil belajar anak usia dini.

Hasil penggalian informasi dan potensi masalah menunjukkan bahwa: (1) Masih minimnya media handmade yang mengangkat kreatifitas guru untuk pengenalan huruf pada anak usia dini, (2) Adanya kelemahan penggunaan buku dan majalah dalam pengenalan keaksaraan awal, (3) Pengenalan huruf dengan media berbasis teknologi tidak dapat dilakukan oleh beberapa lembaga karena keterbatasan kemampuan ekonomi orangtua murid. Uraian masalah ini menjadi dasar untuk perancangan atau desain media yang cocok untuk pengenalan keaksaraan awal pada anak usia dini.

\section{Desain Papan Huruf Flanel}

Produk yang dikembangkan untuk pengenalan keaksaraan awal adalah papan huruf flannel. Produk ini terdiri dari papan yang terbuat dari bahan dasar cartoon board berlapis flannel dengan aneka huruf dari A-Z. Huruf huruf tersebut dibuat pola pada flannel dan ditempelkan pada tutup botol bekas. Tutup botol yang dilapisi flannel huruf tersebut ditempelkan pada cartoon board berlapis flannel. Berikut gambar desain papan huruf flannel: 


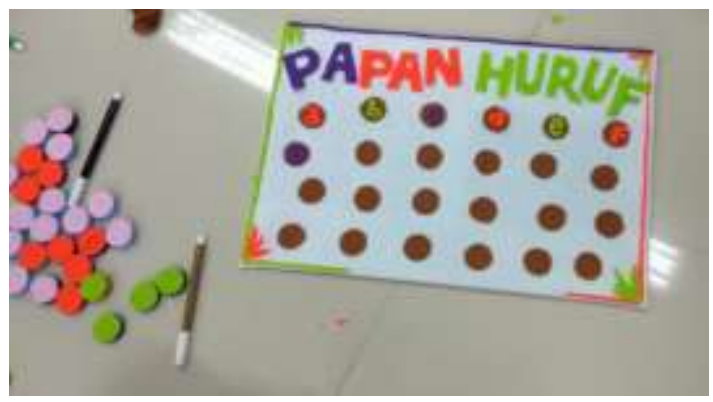

Gambar 3. Desain Papan Huruf

Papan Huruf flannel ini dapat dimainkan dengan flannel huruf yang digunakan untuk permainan mengenal huruf ataupun mengenalkan kosa kata. Flanel huruf adalah pola huruf yang dicetak pada flannel. Papan Huruf ini didesain sedemikian rupa untuk mencegah praktek pembelajaran keakasaraan awal secara klasik. Kegiatan dilaksanankan dengan cara drill dan paper pencil test. Anak dipaksa untuk membaca huruf per huruf. Sehingga anak secara instan dapat menguasai pembelajaran membaca.Tentunya hal ini tidak sesuai dengan perkembangan anak (Sari \& Simatupang, 2017).

Berikut adalah flannel huruf yang dibuat sepaket dengan papan huruf flannel :

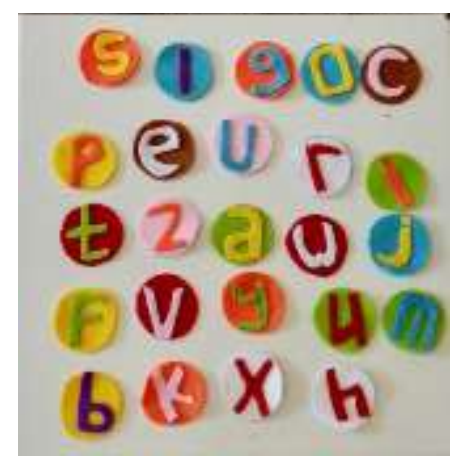

Gambar 4. Flannel Huruf

Flanel huruf yang dikembangkan dalam satu paket dengan papan huruf flannel selain digunakan untuk memainkan permainan memasangkan huruf yang sama, dapat pula dijadikan media untuk permainan pola suku kata. Permainan pola suku kata dapat dilakukan oleh guru untuk mengenalkan huruf pada anak usia dini dan dapat digunakan sebagai metode untuk mengajarkan membaca pada anak melalui bermain (Amini, 2016).

Adanya flannel huruf ini dapat dijadikan sebagai media untuk pengenalan huruf yang menyenangkan. Pada kenyataannya strategi pengenalan huruf sejak usia dini sangat 
AWLADY: Jurnal Pendidikan Anak

Homepage: www.syekhnurjati.ac.id/jurnal/index.php/awlady

Email : pgrasyekhnurjati@gmail.com

P-ISSN: 2541-4658

E-ISSN: 2528-7427
Vol. 5, No. 2, September 2019

10

bermanfaat bagi perkembangan bahasa anak, karena membantu mempersiapkan anak untuk dapat membaca dengan mudah (Ratnasari Dwi Ade Chandra, 2017).

Permainan pengenalan huruf yang banyak dilakukan adalah dengan menggunakan kartu kata dan bergambar. Namun kenyataan yang peneliti amati dilapangan sangat berbeda. Guru kebanyakan hanya mengenalkan simbol-simbol huruf satu persatu dan langsung menyebutkan bunyi hurufnya. Padahal menurut metode sintesa bahwa suatu unsur (misalnya unsur huruf) akan mempunyai makna jika unsur tersebut bertalian atau berhubungan dengan unsur lain sehingga membentuk suatu arti (Guswarni, n.d.).

Penggunaan papan huruf flannel dan flannel huruf ini sebagai upaya untuk membantu anak untuk mengenali huruf sekaligu bermain pola suku kata. Sehingga anak tidak hanya mampu mengenali huruf saat berdiri sendiri namun mampu mengenali huruf dalam pola suku kata.

Permainan susun kata dari flannel huruf pun dapat dilakukan dengan menggunakan media papan huruf flannel ini. Anak semakin mengenal kata yang sering dia dengar dan mengenal tulisan untuk kata itu, misalnya kata toko, buku dan seterusnya. Setiap saat anak melihat huruf dan rangkaian huruf yang kemudian menimbulkan rasa ingin tahu tentang bagaimana mengucapkannya (Kurnia \& Zulkifli, 2016). Dengan demikian pemillihan kata untuk dipraktekan dalam permainan susun kata dapat disesuaikan dengan kata kata yang lazim diucapkan sehari hari.

\section{Validasi Desain dan Perbaikan}

Tahapan ini melibatkan ahli media serta ahli materi dalam hal penentuan kualitas kelayakan produk yang dihasilkan dari pengembangan ini. Ahli Media memiliki kewenangan untuk menilai kelayakan media yang dikembangkan, sedangkan ahli materi memberikan validasi atas kesesuaian materi dengan perkembangan anak usia dini. Masing masing ahli diberikan lembar validasi dengan 4 komponen yakni (1) Kesesuaian dengan perkembangan anak, (2) Kelayakan media, (3) Keawetan media, (4) Keunggulan Media. Berikut ini adalah tabel rangkuman hasil validasi ahli: 
Tabel 1. Rangkuman Hasil Validasi Ahli

\begin{tabular}{l|c|c|c}
\hline Komponen penilaian & $\begin{array}{l}\text { penilaian } \\
\text { ahli media }\end{array}$ & $\begin{array}{l}\text { penilaian ahli } \\
\text { materi }\end{array}$ & $\begin{array}{l}\text { Rata- } \\
\text { Rata }\end{array}$ \\
\hline kesesuaian dengan Pekembangan anak & 4 & 3 & 3,5 \\
kelayakan media & 3 & 3 & 3 \\
keawaetan media & 3 & 3 & 3 \\
keunggulan media & 4 & 3 & 3,5 \\
\hline
\end{tabular}

Hasil validasi yang ditunjukkan pada tabel tersebut di atas menunjukkan range nilai yang akan dikonversikan menjadi penilaian kualitatif. Hasil rata rata ke 4 komponen tersebut dibuat rerata yang nantinya dapat menunjukkan kelayakan media yang telah di kembangkan. Merujuk pada hasil rata rata 4 komponen penilaian yang dinilai oleh dua ahli yakni ahli media dan ahli materi diperoleh rerata nilai 3,25. Hasil rerata ini dikonversikan dengan tabel kritria kelayakan sebagai berikut:

Tabel 2. Kriteria Kelayakan Media

\begin{tabular}{c|c|c}
\hline Nilai & Kriteria & Interval Rerata Skor \\
\hline A & Sangat layak & $4,21>\mathrm{X}$ \\
\hline B & Layak & $3,40<\mathrm{X} \leq 4,21$ \\
\hline C & Cukup layak & $2,60<\mathrm{X} \leq 3,40$ \\
\hline D & Kurang layak & $1,79<\mathrm{X} \leq 2,60$ \\
\hline E & tidak layak & $\mathrm{X} \leq 1,79$ \\
\hline
\end{tabular}

Nilai rerata 3,25 apabila dikonversikan dengan kriteria pada tabel maka produk hasil pengembangan memiliki nilai cukup layak untuk dimanfaatkan sebagai media, dalam hal ini media untuk pengenalan keaksaraan awal. Kegiatan validasi yang dilakukan baik oleh ahli media maupun ahli materi tidak hanya menghasilkan nilai kelayakan media namun ada masukan perbaikan untuk penyempurnaan media. Catatan perbaikan yang disarankan oleh para validator diantaranya: (1) pemilihan warna flanel harap diperhatikan agar menarik bagi anak anak, (2) kerapihan potongan huruf flanel diperbaiki untuk memberikan contoh yang benar simbol huruf pada anak usia dini.

Papan huruf flanel ini merupakan media pembelajaran atau alat permainan edukatif yang disajikan untuk anak usia dini. Pembuatan media ini melibatkan bahan bekas, dalam penyusunan alat permainan edukatif (APE) berbahan dasar bahan bekas harus memperhatikan 6 kriteria khusus yakni; (1) APE dirancang sesuai dengan tujuan, fungsi sarana (tidak 
AWLADY: Jurnal Pendidikan Anak

Homepage: www.syekhnurjati.ac.id/jurnal/index.php/awlady

Email : pgrasyekhnurjati@gmail.com

P-ISSN: 2541-4658

E-ISSN: 2528-7427
Vol. 5, No. 2, September 2019

12

menimbulkan kesalahan konsep (2) APE hendaknya multiguna (3) APE dibuat dengan menggunakan bahan yang mudah didapat di lingkungan sekitar, murah atau dari bahan bekas/sisa (4) menjaga keselamatan, kesehatan, dan keamanan anak (5) APE hendaknya awet, kuat dan tahan lama (5) mudah dalam pemakaian, menambah kesenangan anak untuk bereksperimen dan bereksplorasi (6) dapat digunakan secara individual, kelompok dan klasikal (Hayati, 2019)

Papan Huruf Flannel dan flannel huruf ini dapat memenuhi kriteria alat permainan edukatif (APE) berbahan bekas. Bahan bahan yang digunakan untuk pengembangan media ini menggunakan bahan yang mudah didapat di lingkungan sekitar. Media ini juga memenuhi lima syarat APE lainnya. Keterpenuhan 6 syarat khusus APE berbahan bekas untuk media yang dikembangkan menjadi satu keunggulan bagi produk yang dihasilkan.

Produk yang dihasilkan dalam hal ini papan huruf flanel, tidak hanya divalidasi oleh ahli media namun divalidasi oleh para pengguna. Validasi untuk pengguna ini melibatkan 30 pendidik dari 10 lembaga. Validasi yang dilakukan oleh para pengguna dianggap perlu karena pada kenyataannya yang akan memanfaatkan secara luas adalah para pengguna yakni pendidik ataupun orangtua anak usia dini. Proses validasi untuk pengguna yang dilakukan tidak sampai pada validasi untuk orang tua, hanya melibatkan para pendidik di lembaga pendidikan anak usia dini (PAUD). Kriteria yang dinilai yakni (1) Kemudahan pembuatan, (2) Keawetan media, (3) nilai kreativitas, (4) kemudahan penggunaan. Hasil penyebaran angket penilaian dari pengguna terangkum dalam tabel berikut ini:

Tabel 3. Penilaian Pengguna

\begin{tabular}{c|l|c}
\hline No & \multicolumn{1}{|c|}{ Kriteria } & Jumlah Responden \\
\hline 1 & Kemudahan pembuatan & 19 \\
\hline 2 & Keawetan media & 15 \\
\hline 3 & nilai kreativitas & 28 \\
\hline 4 & Kemudahan penggunaan & 30 \\
\hline
\end{tabular}

kriteria pertama kemudahan pembuatan media papan huruf flanel hanya direspon oleh 19 responden, sehingga hanya 63,3\% responden yang menyatakan bahwa papan huruf flanel 
AWLADY: Jurnal Pendidikan Anak

Homepage: www.syekhnurjati.ac.id/jurnal/index.php/awlady

Email : pgrasyekhnurjati@gmail.com

P-ISSN: 2541-4658

E-ISSN: 2528-7427
Vol. 5, No. 2, September 2019

merupakan media yang mudah untuk dibuat. Nilai keawetan media direspon oleh 15 pendidik atau responden, dengan demikian 50\% menyatakan setuju bahwa papan huruf flanel merupakan media yang awet.

Kriteria nilai kreativitas direspon oleh sekitar 28 responden, hal ini menunjukkan 93 persen responden menganggap bahwa media papan huruf flanel bernilai kreatif sebagai sebuah media untuk anak usia dini. Kriteria terakhir untuk kemudahan penggunaan 100\% dinilai mudah, responden sepakat $100 \%$ bahwa papan huruf flanel mudah untuk digunakan sebagai media untuk pengenalan keaksaraan awal.

Penilaian yang dilakukan responden sama hal nya dengan penilaian oleh ahli media, dimana responden memberikan saran perbaikan untuk media yang dikembangkan. Beberapa saran perbaikan yang diberikan adalah: (1) pemotongan pola huruf harap diperbaiki dan (2) berikan alternatif bahan bekas lain selain flanel dan tutup botol untuk pola huruf pada papan flanel.

Hasil validasi serta saran perbaikan baik dari ahli media ataupun pengguna (pendidik PAUD) dijadikan sebagai modal untuk perbaikan media yang dikembangkan. Langkah selanjutnya yang dilakukan adalah melakukan perbaikan pada media papan huruf kemudian hasil perbaikan tersebut dijadikan produk akhir.

Produk akhir yang dihasilkan berupa papan huruf flannel yang telah diperbaiki pola cetak hurufnya, sebagaimana masukan para ahli saat divalidasi. Perbaikan lain yang dilakukan adalah mengganti pilihan pilihan warna yang kurang menarik untuk bahan dasar flannel dengan warna warna cerah yang menarik minat anak usia dini.

\section{SIMPULAN}

Pengembangan Papan Huruf Flanel untuk media pengenalan keaksaraan awal pada anak usia dini menghasilkan produk yang dinilai cukup layak untuk digunakan sebagai media serta cukup sesuai dengan perkembangan anak usia dini. Berdasarkan hasil validasi dari ahli media dan ahli materi diperleh rerata hasil 3,25 dari skala 1-5, sehingga produk hasil pengembangan ini dianggap cukup layak untuk digunakan sebagai media pembelajaran keaksaraan awal. Hasil Penilaian pengguna (pendidik PAUD) menilai media Papan Huruf Flanel memiliki keunggulan berupa nilai kreativitas dan mudah untuk digunakan. Selain itu dalam sisi kemudahaan penggunaa, terdapat $63,3 \%$ menyatakan bahwa media papan huruf ini 
mudah untuk dibuat. Sementara itu untuk kriteria keawetan sebuah media, papan huruf flannel mencapai hasil 50\% karena separuh dari responden para pengguna media menyatakan bahwa media ini memiliki kriteria keawetan. Demikian hasil penelitian yang telah dilakukan, selanjutnya untuk penelitian berikutnya harapannya dapat melanjutkan tahapan penelitian pengembangan sampai tahap selanjutnya yakni ujicoba efektivitas papan huruf flannel untuk peningkatan kemampuan pengenalan keaksaraan awal.

\section{DAFTAR PUSTAKA}

Yennizar. (2018). Optimalisasi Pengenalan Literasi Pada Anak Usia Dini Melalui Pendekatan Saintifik. JISEC (Journal of Islamic Studies For Early Childhood, 1(1).

Amini. (2016). Meningkatkan Kemampuan Keaksaraan Reseptif Anak Melalui Permainan Pola Suku Kata di Taman Kanak Kanak Negeri Pembina Yogyakarta. Jurnal Pendidikan Anak, 5(1), 673-683.

Fitriyani, N., Tresnawati, D., \& Hadiyanto, N. (2014). Pengembangan Aplikasi Pengenalan Huruf dan Warna untuk Anak Usia DIni Berbasis Android. Jurnal Algoritma, 11(1), 1-9.

Guswarni, E. (n.d.). Peningkatan Kemampuan Membaca Awal Anak Melalui Permainan Kartu Gambar di Taman Kanak Kanak Negeri Pembina Agam. Jurnal Pesona PAUD, $1(1), 1-12$.

Hayati, Z. (2019). Penggunaan Alat Permainan Edukatif (APE) dari Botol Plastik dan Koran Bekas untuk Meningkatkan Kreativitas. AWLADY: Jurnal Pendidikan Anak, 5(1).

Indriyani, F., \& Sihite, K. R. (2015). Pengenalan Huruf, Angka dan Warna Pada Anak Usia Dini Melalui Pembelajaran Berbasis Multi Media. Paradigma, XVII(1), 28-35.

Izzaty, R. E., Cholimah, N., \& Wulandari, R. (n.d.). Pengembangan Buku Cerita Tematik Sebagai Media Pembelajaran Pengenalan Membaca Pada Anak Prasekolah.

Kemdikbud. Permendikbud 137 Tahun 2014 (2014).

Kurnia, R., \& Zulkifli, N. (2016). Efektivitas Pemanfaatan Alat Permainan Edukatif (APE) Bahan Lokal Untuk Meningkatkan Kemampuan Bahasa Pada Anak Usia 5-6 Tahun di Taman Kanak Kanan Melati Dharma Wanita Air Tiris Kecamatan Kampar. EDUCHILD, 5(1), 27-36.

Maulidya, A. R., Sa'dullah, A., \& Lismanda, Y. F. (2019). Peningkatan Kemampuan Mengenal Huruf Vokal Melalui Media Pohon Huruf Pada Anak Usia 3-4 Tahun di Kelompok Bermain Stroberi Restu 1 Malang. Dewantara: Jurnal Ilmiah Pendidikan Islam Anak Usia Dini, 1(2), 1-9.

Muflikha, E. S. (2013). Peningkatan Kemampuan Anak Mengenal Huruf Melalui Media Tutup Botol Hias di PAUD Kenanga I Kabupaten Pesisir Selatan. Spektrum PLS, 1(1).

Nuraeni, A. (2016). Peran Orang Tua dalam Pengembangan Literasi Dini Anak Kelompok B 
di Gugus 7 Mangunan Dlingo Bantul. Jurnal Pendidikan Anak Usia Dini, 5(3), 245-256.

Pangastuti, R., \& Farida, S. (2017). Pengenalan Abjad pada Anak Usia Dini Melalui Media Kartu Huruf. Al Hikmah: Indonesia Journal of Early CHhildhood Islamic Education, $1(1), 51-66$.

Putra, L. D., \& Ishartiwi. (2015). Pengembangan Multimedia Pembelajaran Interaktif Mengenal Angka dan Huruf untuk Anak Usia Dini. Jurnal Inovasi Teknologi Pendidikan, 2(2), 169-178.

Ramadani, R. (2015). Membaca Permulaan Melalui Kegiatan Menebalkan Huruf. Jurnal Pendidikan Anak, IV(1), 582-587.

Ratnasari Dwi Ade Chandra. (2017). Pengembangan Media Visual Kartu Angka Efektif untuk Mengenalkan Huruf Vokal A,I,U,E,O Pada Anak Usia Dini 3-4 Tahun PAUD Labschool Jember. INDRIA, Jurnal Ilmiah Pendidikan PraSekolah Dan Sekolah Awal, II(1), 45-71.

Sari, F. D., \& Simatupang, N. D. (2017). Pengaruh Penggunaan Media Permainan Papan Flashcard Terhadap Kemampuan Keaksaraan Anak Kelompok A TK Putra Airlangga Surabaya. Jurnal PAUD Teratai, 6(3).

Sugiyono. (2013). Metode Penelitian Pendidikan (Pendekatan Kuantitatif, Kualitatif, dan $R \& D)$. Bandung: Alfabeta.

Suhermin. (2019). Penerapan Media Flashcard untuk Meningkatkan Kemampuan Keaksaraan Awal Peserta Didik Kelompok A di RA Muslimat NU Al Hikmah Wagir Malang. Jurnal Dewantara, 1(1), 19-24. 